\title{
ARCHITECTURAL CONTROLS AND THE INDIVIDUAL LANDMARK
}

\author{
JOHN S. PYKe, JR.*
}

Architectural controls, or as they are more accurately termed, design and demolition controls, are now widely accepted as an effective means to protect and preserve structures which have a special value to the community because of historical, aesthetic, or cultural significance. Municipalities ranging in size from New York City and Chicago to Binghamton, New York, and Lake Forest, Illinois, have adopted ordinances regulating the demolition of landmark structures and the changes that may be made in the exterior appearance and design of such structures.

This article will examine the application of design and demolition controls to the individual landmark property. There will be an attempt to identify the legal justification for imposing such controls on a single landmark structure in an otherwise historically insignificant neighborhood, while leaving unaffected the buildings surrounding the regulated structure. The question is of importance because such controls infringe on the landmark owner's right to use his property as he desires and require him to bear, perhaps involuntarily, the cost of preserving a structure which others have deemed worthy of preservation. Also considered are the particular devices employed in preservation ordinances to balance the public's interest in historic preservation with the economic interests of the private owner.

\section{REgULATING THE IsOLATEd LaNDMARK}

The use of the police power to preserve landmarks initially took the form of an ordinance to protect the special character of an historic district. ${ }^{1}$ The term historic district is used herein as it is typically used in the ordinances, namely, to refer to an area which has a special historic or aesthetic value. In the earliest cases which established the validity of design and demolition controls, state appellate courts construed and upheld regulations applicable to defined districts. ${ }^{2}$ Controls over districts were extended to individual landmark structures, beginning in the midI950's. ${ }^{3}$ Today the value of regulating structures both as a class within an historic

* Attorney, The Hanna Mining Company and author of Landmark. Preservation (1969).

${ }^{1}$ New Orleans (I925) and Charleston, South Carolina (I93I), were among the first cities to adopt preservation ordinances; the ordinances created and regulated a single historic district in each city. J. Morrison, Historic Preservation Law r29-86 (r965).

${ }^{2}$ City of New Orleans v. Pergament, I98 La. 852, 5 So. $2 \mathrm{~d}$ I29 (194r); Opinion of the Justices to the Senate, 333 Mass. 773, 128 N.E.2d 557 (I955); Opinion of the Justices to the Senate, 333 Mass. 783, r28 N.E.2d 563 (I955).

${ }^{3}$ Philadelphia, $\mathrm{Pa}$. was the first city to regulate individual landmarks whatever their location. Tinkcom, The Philadelphia Historical Commission: Organization and Procedures, 36 LAw \& ConTeMp. Pros. 386 (I97I). 
district and as individual structures wherever they may be situated is widely acknowledged; recent ordinances commonly include both types of structures under the regulatory umbrella. ${ }^{4}$ The question then becomes, does the legal justification for historic district regulation also support regulation of individual landmarks scattered throughout a city?

While the law of zoning serves as the principal precedent for historic district regulation and is a well-recognized exercise of the police power, it offers only partial support for regulation of isolated landmarks. If zoning is defined as the territorial division of a city according to uniformities of use within each division, ${ }^{5}$ then the law of zoning will be of little service as precedent when a municipality regulates by ignoring districts and imposing controls on scattered structures. The Louisiana Supreme Court upheld the Vieux Carre regulations in City of New Orleans v. Pergament, precisely because they applied to a district: "The purpose of the ordinance is not only to preserve the old buildings themselves, but to preserve the antiquity of the whole French and Spanish quarter, the tout ensemble...." To this Court at least, the whole was greater than its parts.

Moreover, any attempt to justify regulation of isolated landmarks as part of a zoning scheme runs the risk of exposing the regulations to attack as spot zoning. The very antithesis of planned zoning, spot zoning is the arbitrary singling out of one parcel for treatment different than that accorded to surrounding parcels and it it universally condemned by all state courts as an improper exercise of the police power.

Court decisions in zoning cases do yield some arguments justifying the imposition of controls over isolated landmarks. Both the Louisiana Supreme Court in upholding the Vieux Carre ordinance and the Massachusetts Supreme Court in upholding the Nantucket Historic District Act referred to the value of the districts as tourist attractions. ${ }^{7}$ The same reasoning will justify regulation of the individual landmark which itself is a tourist attraction, such as New York City's J. P. Morgan and Company Building at Broad and Wall Streets, or St. Patrick's Cathedral.

The view that zoning ordinances based predominantly or purely on aesthetic considerations are proper exercises of the police power has been firmly established by the New York courts, and a number of other state courts have accepted this point of view. ${ }^{8}$ Therefore, even if the isolated landmark is not itself a tourist attraction but is solely a beautiful building, regulation of its alteration or demolition might

\footnotetext{
‘See, e.g., Chtcago, Ill., Rev. Munictpal Code $\$ \S 2 \mathrm{I}-64$ (1968).

'See 101 C.J.S. Zoning \& I (1958).

${ }^{\circ}$ City of New Orleans v. Pergament, 198 La. 852, 5 So. $2 \mathrm{~d}$ I29 (I94I).

${ }^{7}$ City of New Orleans v. Pergament, I98 La. 852, 5 So. 2d (I94I); Opinion of the Justices to the Senate, 333 Mass. 773, I28 N.E.2d 557 (1955); Opinion of the Justices to the Senate, 333 Mass. 783,128 N.E.2d 563 (1955).

${ }^{8}$ Sailors' Snug Harbor v. Platt, 29 A.D.2d 376, 288 N.Y.S.2d 314 (xg68); Cromwell v. Ferrier, I9 N.Y.2d 263, 225 N.E.2d 749 (1967). See Henley, Beautiful as Well as Sanitary-Architectural Controls by Municipalities in lllinois, 59 IrI. B.J. 36 (1970).
} 
be justified in those states holding the more liberal view on the grounds that it promotes aesthetic objectives.

There are several possible approaches to regulating the isolated landmark in the context of a local zoning ordinance, and among these are the so-called "floating zone" and the "mini-district." These have much in common: they both are incorporated into the local zoning ordinance, both achieve substantially the same result, and both have misleading nomenclature.

These techniques are of fairly recent origin and were created in an attempt to give municipal authorities more flexibility in regulating individual uses of property with respect to location, site planning, and design. They are in part an attempt to maintain the strong federal and state constitutional mandates to secure uniformity in the application of regulations and to avoid the granting of special privileges and emoluments, while at the same time enabling a city to deal more flexibly and precisely with individual owners of property. Generally they are framed to meet the requirement in virtually all state zoning enabling acts that regulations affecting the use of property be uniform throughout each district.

The "floating zone," in reality, does not float. Essentially it is a zoning category, defined in the text of an ordinance, which has specified criteria for eligibility rather than a fixed geographical location. By adopting criteria for qualification, the governing body makes an advance statement of the terms and conditions under which it will rezone individual properties to the floating zone category at the request of any owner who can demonstrate at any time that his property meets the specified criteria. In the case of the floating landmark zone, the ordinance would also impose design and demolition controls, and possibly other requirements, on properties rezoned to the landmark category. At the time of enactment of the ordinance, individual properties might or might not be contemporaneously rezoned to the new classification. Until rezoning occurred, nothing would show on the zoning map itself, and the text provisions in the ordinance would remain as a mere statement of intent by the governing body as to how it will deal with individual situations in the future. Thus the floating zone is basically a procedural device, affording the governing body an opportunity to announce prior to a rezoning what it will do when the criteria are met by the individual petitioner.

Although the floating zone was originally designed to deal with uses of property for which no precise location could be nailed down in advance-such as a shopping center and some types of housing development-it serves a wholly different purpose in municipal preservation programs. Most historic and aesthetic landmarks have a fixed location and are well known at the time the ordinance creating the floating zone is adopted. The floating landmark zone is employed in preservation programs as a selective tool to extend design and demolition controls to individually significant structures. It permits a technically qualified body, such as a landmarks commission, to decide on a case by case basis whether an individual property should be reclassified and regulated as a landmark. Thus, the New York City statute authorizes the 
Landmarks Preservation Commission to designate landmark structures as well as landmark districts on the basis of specified criteria of historical and architectural significance, and imposes design and demolition controls on both designated structures and districts. ${ }^{\circ}$

The "mini-district" approach achieves exactly the same end result as the floating zone by establishing what are essentially one- or two-property special zoning districts encompassing one or several individually significant landmark structures. Procedurally, the establishment of the mini-district in the text of the ordinance might or might not be accompanied by the simultaneous rezoning of a number of individual properties to the new classification. Precise controls with respect to lot size, design and demolition, and the permitted uses of the property would be spelled out in detail in the district regulations. For all practical purposes, the mini-district would not be unlike any other zoning classification.

The terms "floating zone" and "mini-district" would be unimportant except that they serve to seriously mislead and confuse planners and lawyers alike. What is important is that both approaches are potentially capable of being unhorsed as "spot zoning," which is a third misleading term. To condemn a regulation as spot zoning is equivalent to saying that the governing body acted arbitrarily and capriciously in singling out one or two properties for demonstrably unequal treatment. Avoiding the stigma of spot zoning in this case must depend on the argument that it is not unequal, unreasonable, or arbitrary to treat historical properties differently from their unexceptional neighbors. ${ }^{10}$ Since the permitted distinctions in zoning classification usually rest upon the location of the property and the characteristics of the neighborhood rather than factors intrinsic to the property itself, courts must be persuaded to accept historical and aesthetic distinctions in addition to geographical ones.

Norfolk, Virginia, is one of a few cities to experiment with the "mini-district" approach, by proposing a new classification called the Historical and Cultural Conservation District. ${ }^{11}$ Norfolk seeks to minimize the spot zoning problem by requiring that petitions for rezoning property to the Historical and Cultural Conservation District may be put forth only by a public body (thereby avoiding any show of private gain) "for a purpose appropriate to comprehensive planning principles, and one which may indeed be a key element in the success of the comprehensive plan for the area." ${ }^{212}$ This is important in view of another typical requirement of most state zoning enabling acts, that the regulations must be "in accordance with a comprehensive plan." In this case the "comprehensive plan" or policy is to provide special treatment for historic landmarks wherever they are located, in a fashion analogous to zoning provisions sometimes found elsewhere allowing "mom-and-pop" grocery

\footnotetext{
' NeW York, N.Y., ADMinistrattVe CODE ch. 8-A.

${ }^{10}$ Comment, Legal Methods of Historic Preservation, Ig Bufraro L. Rev. 6rI, 620 (1970); Schatzel, Public Historic Preservation in Texas, 49 TEx. L. Rev. 267, 3I7 (I97I).

${ }^{11}$ Norfolk, VA., CODE OF THE City OF NORFols $\$ \$ 490-98$ (I968).

${ }^{12}$ Preserving Norfolk's Heritage, Proposed Zoning for Historic and Cultural Conservation, published by the Department of City Planning, Norfolk, Va. 22 (1965).
} 
stores anywhere in the city including residential districts from which commercial uses would otherwise be excluded.

The feasibility of this approach would also seem to depend on the absence in the zoning enabling legislation of any minimum size requirement for a given district, plus, perhaps, local rules of construction favorable to the notion that the use of the term "buildings or places of historical interest" also includes the singular, or individual, building or place.

It should be noted, of course, that the use of the floating zone and the minidistrict in a landmark context have yet to be tested and approved in court.

\section{II}

\section{Protecting the Landmark Owner's Property Rights}

To their credit, preservationists approach design and demolition controls from the point of view of the community's need to preserve and maintain its areas and structures of historical, aesthetic, and cultural importance for future generations to enjoy. Legal, practical, and other considerations dictate that the ordinances creating design and demolition controls also be examined in terms of the landmark owner and the present enjoyment of his property rights. As used here, the term landmark owner includes the owner of an isolated landmark as well as the owner of a structure in an historic district.

Design and demolition controls infringe on and restrict the landmark owner's right to use his property. Changes in the exterior appearance of a landmark structure or the destruction of a landmark building and its replacement by a more profitable one cannot be undertaken without the prior approval of the regulatory agency administering the controls. ${ }^{13}$ All state courts have recognized, however, that police power regulations, such as zoning, may limit and restrict the use of real property for the common good of the community. ${ }^{14}$

Ordinances imposing design and demolition controls on the activities of landmark owners within and outside of historic districts have been tested in the courts of Illinois, Louisiana, Massachusetts, and New York and upheld in each instance as valid and proper exercises of the police power. ${ }^{15}$ Nevertheless, if the regulations,

\footnotetext{
${ }^{13}$ For a discussion of the operation of design and demolition controls, see Note, Land Use Controls in Historic Areas, 44 NOTre DaMe LAWYER 379 (1969).

${ }^{14}$ ror C.J.S. Zoning $\$ 37$ (1958); Comment, The Police Power, Eminent Domain, and the Preservation of Historic Property, 63 CoLUM. L. REv. 708, 713 (1963). For the expression of the contrary view that design and demolition controls may be unconstitutional without provision for compensation see Comment, Landmark Preservation Laws: Compensation for Temporary Taking, 35 U. CHI. L. REv. 362 (I968).

${ }^{16}$ Rebman v. City of Springfield, III Ill. App. 2d 430, 250 N.E.2d 282 (1969); M\&N Enterprises v. City of Springfield, III Ill. App. $2 d$ 444, 250 N.E.2d 289 (Ig69); City of New Orleans v. Levy, 223 La. I4, 64 So. 2d 798 (r953); City of New Orleans v. Impastato, r98 La. 205, 3 So. 2d 559 (r941); City of New Orleans v. Pergament, r98 La. 852, 5 So. $2 d$ r29 (I94I); Opinion of the Justices to the Senate, 333 Mass. 773, 128 N.E.2d 557 (1955); Opinion of the Justices to the Senate, 333 Mass. $783, \times 28$ N.E.2d 563 (1955); Manhattan Club v. Landmarks Preservation Commission, 5I Misc. 2d 556, 273 N.Y.S.2d 848 (Sup. Ct. I966); Sailors' Snug Harbor v. Platt, 29 A.D.2d 376, 288 N.Y.S. 3I4 (r968).
} 
even though a constitutional exercise of the police power, cast too substantial a burden on the individual landmark owner, they may constitute an unlawful invasion of his right of private property which would require the municipality to compensate the owner. ${ }^{16}$ In order to determine whether an ordinance regulating design and demolition controls interferes with the manner in which the landmark owner uses his property to a degree amounting to a confiscation of the property, a court is likely to ask whether the design and demolition restrictions preclude use of the property for any purpose for which it is reasonably adapted. ${ }^{17}$ Merely depriving the owner of the most beneficial or profitable use of his property does not render the ordinance unconstitutional..$^{18}$

Preservationists must recognize and act on the fact that a landmark owner who is unreasonably restricted from altering or demolishing his landmark must either be compensated for the burden he is asked to carry in the public interest, or be freed from the restrictive regulations. Thus, a landmarks preservation ordinance must accommodate itself to the individual hardship situation. This is not only a mandate of the federal and state constitutions but also a practical, political necessity. It will be difficult, if not impossible, to persuade a city council to adopt an ordinance which does not contain some relief provisions. Councilmen tend to be sensitive to unduly burdensome restrictions which may result in unhappy constituents. If there are no relief provisions in the ordinance, the regulatory agency will meet stiff opposition both in designating the landmark and administering the controls. The net result will be a hostile group of owners and an ineffective agency.

A number of methods have been devised to adjust the landmark owner's property interest to the public's interest in preserving the structure. While many of these methods have been the subject of litigation, to date no preservation ordinance containing any of these adjustment provisions has been struck down as confiscatory.

It should be pointed out that in some rare instances the public interest may be deemed, legislatively at least, always to outweigh the private burden. The Schenectady, New York, ordinance assumes that pre-1925 buildings are of such importance to the community that demolition should be absolutely prohibited, unless the building has become a public safety hazard. ${ }^{19}$

Probably the most common relief provision in landmark preservation ordinances is the requirement that an owner, who proposes to alter or demolish a building, must postpone his alteration or demolition plans for a specified period. What period of delay would be upheld by a court as reasonable cannot be answered with certainty.

\footnotetext{
${ }^{10}$ Pennsylvania Coal Co. v. Mahon, 260 U.S. 393 (I922); I P. Nichols, EMINENT Domain § I.42(I0) (Rev. 3d ed. Ig67).

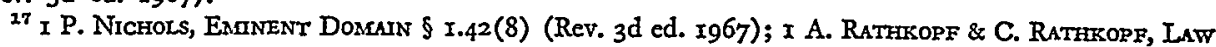
of Zoning and Planning 6-1o (3d ed. 1956); Forrest v. Evershed, 7 N.Y.2d 256, ig6 N.Y.S.2d 958 (1959).

${ }_{18}$ Teuscher v. Westport, I54 Conn. 650, 228 A.2d 5I8 (I967) (beneficial use); Rebman v. City of Springfield, III Ill. App. 2d 430, 250 N.E.2d 282 (I969) (profitable use).

10 Schenectady, N.Y., General City Law Ordinances No. I4221, § 7-c (1962).
} 
In some situations a postponement of one month might cause a substantial loss, whereas in others a postponement of one year might result only in inconvenience. The actual delay period stipulated in various ordinances, aside from any periods for fling documents, holding hearings, etc., varies widely from one municipality to another. Charleston, South Carolina, authorizes a three month delay; ${ }^{20}$ Richmond, Virginia, stipulates six months; ${ }^{21} \mathrm{New}$ York City allows up to one year; ${ }^{22}$ Madison, Wisconsin, sets six months for alterations and one year for demolitions; ${ }^{23}$ and Alexandria, Virginia, specifies time periods for pre-1 846 buildings ranging from three months to twelve months, depending on the fair market value of the property involved. ${ }^{24}$

The purpose of the postponement is to afford an opportunity to the regulatory agency and other interested parties, both public and private, to reappraise the historical and aesthetic value of the landmark and to develop a feasible alternative preservation plan. The plan may be based upon the voluntary consent of the owner, as for example the sale of the property to a preservation-minded buyer, or acceptance of a restrictive covenant or a preservation easement. Or it may not require his consent, such as in a case where the municipality decides to exercise its power of eminent domain and acquire the landmark for public use.

The postponement approach carries with it the ultimate assurance to the owner that if he follows the statutory procedures, he will eventually be free of the restrictions. In spite of this obvious invitation to the owner simply to sit and wait out the prescribed period, it has proved to be an extremely useful preservation tool..$^{25}$ In the first place, the application procedures for a permit to alter or demolish open the door for the commencement of a preservation dialogue with the owner. Preservationists are alerted to the problem and are granted a grace period to organize private or public action to prevent irreparable loss. And finally, the determined owner soon finds himself centrally involved in the preservation process since he must cooperate with the regulatory agency in order to perfect his right to be free of the regulation. That involvement can be fatal to his alteration or demolition plan because it gives the agency an opportunity to educate the owner in terms of historic conservation and, perhaps, to change his point of view.

Various tax incentives offer another method for lightening the burden of the regulations on the landmark owner to the point where he will be willing and able to comply with the regulations. The Commonwealth of Puerto Rico and New York City both incorporate special tax benefit provisions in their statutes. ${ }^{2 \mathrm{~B}}$

\footnotetext{
${ }^{20}$ MORRISON, supra note $I$, at I33.

${ }^{21}$ RichMoNd, VA, CODE OF THE CITY OF RICENMOND $\$ \S 52-249$ to 53-II (I953).

${ }^{22}$ New YORK, N.Y., ADManistrative CODE $\$ 205-8.0 \mathrm{~g}(2)$ (1965).

${ }^{28}$ Madison, Wis., Madison Generat Ordinances $\$ 33.01$ (5) (1970).

24 Alexandria, VA., CODE OF the CITY OF Alexandria art. XIV (I963).

25 Tinkcom, supra note 3, at 393; Interview with Frank B. Gilbert, Secretary, New York City Landmarks Preservation Commission, Oct. 3, 1970.

${ }^{26}$ See note following Law of June 27 , I969, tit. 13, $\$ 55 x$, [1970] Laws of Puerto Rico Ann. 256; New YoRk, N.Y., ADMinistrative CODE $\$ 205-8.0 c$ (1965). See also Wilson and Winkler, The Response of State Legislation to Historic Preservation, 36 LAW \& CONTEMP. ProB. 329 (I97r).
} 
Chicago has put forth still another method of relief in an ordinance which provides that the owner who wishes to alter or demolish his landmark has the right to compel the city to decide whether it will exercise its power of eminent domain and compensate the owner, or whether it will release him from the regulations. ${ }^{2 \pi}$ The owner is also required to postpone his plans to alter or demolish for a specified period in order to permit the Chicago City Council to take such action. ${ }^{28}$

The Chicago approach can be carried one step further by establishing in advance a measurable point at which the burden of the restrictions will be deemed to be too heavy for the owner to bear. Once that point is reached, the municipality must then take the initiative and decide whether it wishes to pay compensation or release the owner from the restrictions. The New York City ordinance embodies this concept of an objective standard to determine when the restrictions constitute a "taking," and provides for action to be taken by the regulatory agency to alleviate the affected property owner's hardship. If the owner of a New York landmark can show that he cannot realize a reasonable return from his property-"reasonable return" is defined as a net annual return of $6 \%$ on the current assessed value of his property-he thereby imposes an obligation on the New York City Landmarks Preservation Commission to devise a preservation plan, which may include tax exemptions or acquisition by the city, within a specified time period. ${ }^{29}$ If the city's efforts do not produce positive results, the owner is at liberty to proceed without the encumbrance of the regulations. In Ig66 the New York Supreme Court upheld this general approach in Manhattan Club v. Landmarks Preservation Commission, stating that "the statute is not confiscatory. Petitioner is free to do as it pleases with the interior of the building. It is guaranteed a reasonable return on its investment. And if no plan can be devised to materialize this guarantee, it may make such changes as it wishes. ${ }^{30}$

\section{Conclusion}

As one observer has noted, "Preservation, like any other form of zoning, involves a close and difficult balancing of public necessity and private interest." ${ }^{31}$ Preservation problems created by design and demolition controls can and must be solved in a manner which accommodates the interests of the community to those of the landmark owner. While there is a paucity of specific judicially-endorsed guidelines to aid in reaching these solutions, there are a multitude of legislative precedents and techniques available for protecting both the landmarks and the landmark owner's property rights.

\footnotetext{
${ }^{27}$ ChICAgo, III., REv. MUNICIPAL CODE $\S 2 \mathrm{I}-64 . \mathrm{I}$ (1968).

${ }^{28}$ Id.

${ }^{20}$ New York, N.Y., AdMinistrative Code $\$ 205-8.0 c$ (1965).

${ }^{30}$ Manhattan Club v. Landmarks Preservation Commission, 5I Misc. 2d 556, 560, 273 N.Y.S.2d 848, 852 (Sup. Ct. rg66).

${ }^{31}$ Comment, supra note $x_{4}$, at 732 .
} 